\title{
Molecular mechanism of the anticancer effect of sweet red pepper extract
}

\author{
Karim Samy El-Said ${ }^{1 *}$, Ehab Mostafa Ali ${ }^{1}$, Maisa Mohamed Abd Elhamid1, El-Refaie Kenawy ${ }^{2}$ \\ ${ }^{1}$ Biochemistry Division, Chemistry Department, Faculty of Science, Tanta University, Egypt \\ ${ }^{2}$ Chemistry Department, Faculty of Science, Tanta University, Egypt
}

\begin{tabular}{|c|c|}
\hline ARTICLE INFO & ABSTRACT \\
\hline $\begin{array}{l}\text { Keywords: } \\
\text { Cancer, Sweet red pepper, } \\
\text { Antioxidants, Anticancer, Apoptosis } \\
\text { Abbreviations } \\
\text { RT-PCR, real time polymerase chain } \\
\text { reaction } \\
\text { GAE, gallic acid equivalents } \\
\text { TAC, Total antioxidants capacity } \\
\text { Tam, Tamoxifen }\end{array}$ & $\begin{array}{l}\text { Background: Having non-toxic anticancer agents are targeted by } \\
\text { researcher in the biomedical field around the world. Cancer-fighting } \\
\text { phytochemicals have been potentially identified in several medicinal } \\
\text { plants for cancers therapy. Apoptosis paid a great promise to study } \\
\text { mechanism of cancer treatment. Objectives: This study aimed to } \\
\text { investigate the antioxidants activities of the aqueous ethanolic extract of } \\
\text { sweet red pepper (Capsicum Spp.) and its effects on colorectal cancer cell } \\
\text { lines (CaCO-2). Methods: Phytochemical constituents and anticancer } \\
\text { efficacy of sweet red pepper extract were evaluated. The apoptotic } \\
\text { mechanism of the extract was proved by using real time polymerase chain } \\
\text { reaction (RT-PCR) for apoptotic related genes (Bax, caspase } 3 \text { and Bcl-2). } \\
\text { Results: The results showed that sweet red pepper extracts exhibited } \\
\text { powerful antioxidant activities. Moreover, this extract could trigger } \\
\text { apoptosis in human colorectal tumor cells by overexpressing apoptotic } \\
\text { genes (Bax and caspase } 3 \text { ) and down-expressing the anti-apoptotic Bcl-2 } \\
\text { genes. Conclusion: The sweet red pepper extract could inhibit CaCO-2 } \\
\text { cellular proliferation by inducing apoptosis due to their phytochemical } \\
\text { contents. }\end{array}$ \\
\hline
\end{tabular}

\section{INTRODUCTION:}

Cancer led to million deaths all over the world, particularly, colorectal malignancy is tumor-related deaths [1]. Recently, two million new different cancer cases were diagnosed and more than half million-cancer death was occurred in United States ${ }^{[2]}$. Colorectal cancer development is a multi-factorial including family history, age, gender, high-fat diets, diabetes, inflammatory bowel diseases, ulcerative colitis and lack of physical activity ${ }^{[3,4]}$. Chemotherapy is common to treat different types of cancer; however, its side effects on normal tissues still one of the most restricted reasons to use it as the optimal drug of choice. Upon the treatment with the chemotherapy, several side effects such as leucopenia and cardio-toxicity have been reported caused by oxidative stress ${ }^{[5,6]}$. Finding new natural therapeutic agents as anticancer agents have been reported ${ }^{[7]}$.

Phytochemicals are crucial for health care and potentially used in the prevention and treatment of vigorous diseases such as cancer and cardiovascular disorders ${ }^{[8]}$. Phenolic compounds are identified as plants secondary metabolites. For instance, flavonoids, phenols, tannins, lignins, coumarins and xanthones have been used in pharmaceutical studies with high impact in cancer treatment [9]. The health beneficial effects of these polyphenols showed anti-carcinogenic activities that

Corresponding Author: Dr. Karim Samy El-Said, Ph.D.

Lecturer of Biochemistry, Faculty of Science, Tanta University

Tanta, 31527, Egypt.

Telephone: +202 - 01002977062

Fax: +202 - 0403350804

E-mail: kareem.ali@science.tanta.edu.eg 
could be due to cell cycle arrest or apoptotic promotion ${ }^{[10]}$.

Red sweet pepper (Capsicum Spp.) is a vegetable with potential antioxidant efficacy that belonging to Solanaceae family ${ }^{[11]}$. They contain essential vitamins such as pro-vitamin A and vitamin C. Furthermore, sweet red peppers exhibit high content of natural constituents such as quercetin, luteolin, and capsaicinoids [12]. Sweet red peppers are promising source of pharmacological bioactive compounds majorly phytochemicals and essential oils make them potential antioxidant, antiinflammatory, anti-mutagenic, antihemorrhagic and anti-cancerphytonutrients [13-16]. These phytochemicals could support immune function and useful for therapeutic purposes in the treatment of asthma, arthritis, rheumatism and reduces cancer and cardiovascular disease risks ${ }^{[17]}$. Furthermore, it has been reported that red sweet pepper extracts improve the status of experimental animals with streptozotocininduced diabetic neuropathy ${ }^{[18]}$.

The pathogenesis of colorectal cancer and chemotherapeutic resistance may be due to the disturbances in apoptotic pathways. Food constituents including polyphenols, glucosinate, flavonoids; butyrate and capsaicinoids secondary products are known to prevent colorectal cancer development by enhancing DNA damage followed by apoptosis [19]. Therefore, in the current study, the efficacy of sweet red pepper extracts as antioxidants was assessed by analyzing their phytochemicals content and the study was extended to evaluate the anticancer efficacy of the extract and the molecular mechanism by which this extract induce apoptosis in human colorectal tumor cell lines via determining the expression of main genes involved in apoptosis.

\section{MATERIALS AND METHODS: Plant materials and pepper extract}

Sweet red pepper plants were purchased from the Carfour hyper in Tanta City, Egypt. The plant materials were identified by taxonomist at Botany Department, Faculty of Science, Tanta University. Vegetables were cut, dried in shed at room temperature and then grounded to obtain fine powder. Fifty grams of the grinded plants were extracted in $500 \mathrm{ml}$ of $70 \%$ ethanol. Samples were filtered and the crude extracts were used for the assessment of antioxidants and anticancer properties.

\section{Total phenolic contents}

The content of the total phenolic in the sweet red pepper extract were assessed by using the Folin-Ciocalteau reagent. Briefly, the extract solutions $(100 \mu \mathrm{l})$ were added to working Folin reagent $(1 \mathrm{ml})$ and $1 \mathrm{ml}$ sodium bicarbonate solution. Then, this mixture was incubated for $15 \mathrm{~min}$. By using a spectrophotometer (Biowave, S2100, UK) determining the absorbance of the resulting color at $730 \mathrm{~nm}$ was obtained. The gallic acid calibration curve was used to obtain the corresponding concentration of the total phenolic in the sweet red pepper extract. The unit of the total phenolic was mg GAE/g extract.

\section{Total flavonoids contents}

Total flavonoids were determined by using the colorimetric method of aluminum chloride, quercetin was used as a standard. Briefly, half milliliters of the aqueous ethanolic extract solution was mixed with 5\% sodium nitrate. Post 6 min, aluminum chloride and sodium hydroxide were added and left for $15 \mathrm{~min}$. UVVisible Ultraspec 2000 spectrophotometer was used to read the absorbance of the mixtures at $510 \mathrm{~nm}$. The total flavonoids content were calculated as milligrams of quercetin equivalents.

\section{Total antioxidants capacity (TAC)}

By using phosphomolybednum method, the total antioxidant capacity was evaluated in the red pepper extract that expressed as ascorbic acid equivalent. Briefly, $100 \mu \mathrm{l}$ of the hydro-alcoholic extract were mixed with molybdate reagent solution, incubation $(90 \mathrm{~min}$ at 95 ${ }^{\circ} \mathrm{C}$ ), and then cooled for 20-30 min and the absorbance was measured at $695 \mathrm{~nm}$. 
Free radicals scavenging activity by DPPH

The crude extract was used for evaluating the free radicals scavenging capacity spectrophotometrically. Briefly, $100 \mu \mathrm{l}$ of the crude extract was added to 2 $\mathrm{ml}$ of freshly prepared DPPH $(0.0025 \%)$ solution and post $30 \mathrm{~min}$. The sample solution $\left(\mathrm{A}_{\mathrm{s}}\right)$ and control solution $\left(\mathrm{A}_{\mathrm{c}}\right)$ absorbance's were provided at $517 \mathrm{~nm}$.

\section{Saponin and anthocyanin contents}

According to the methods by Ebrahimzadeh and Niknam (1998), saponin and anthocyanin contents in the sweet red pepper extract were determined [20].

\section{Cell culture and $\mathrm{CaCo-2}$ cell lines}

The human colorectal cancer cell line CaCo-2 cells were purchased from VACSERA Tissue Culture Unit (Cairo, Egypt). These cells were propagated in its suitable medium and then centrifuged at $1500 \mathrm{rpm}$ for 5 minutes. Cell pellets were re-suspended in culture medium for cellular passaging at stabilizing conditions. Culture renewal was performed at cellular confluence (70-80\%). Logarithmically growing cells were used for all the experiments.

\section{Cytotoxicity analysis by MTT assay}

The MTT assay protocol was used to check the cytotoxic effects of the extracts on CaCo-2 cells. By diluting the extract in saline at different concentrations (5-100 $\mu \mathrm{g} / \mathrm{ml})$, the $70-80 \%$ confluent $\mathrm{CaCo}-2$ cells were exposed to the extracts concentrations in triplicate, incubated at suitable conditions for 24 hours and then, $10 \mu \mathrm{l}$ MTT solution was added to each well. This was followed by incubation for $4 \mathrm{~h}$ at $37{ }^{\circ} \mathrm{C}$. The MTT solution was eliminated, and the purple formazan crystals produced were dissolved in DMSO. Tamoxifen (Tam) is a positive standard. By using ELIZA reader (StatFax-2100, Awareness Technology, Inc.), the absorbance of the purple color could be detected at $570 \mathrm{~nm}$. The certain concentration that showed half of colon tumor cells death (IC50) was detected from the sigmoidal curve.

\section{Gene expression analysis by real-time} quantitative polymerase chain reaction

Extraction of the total RNA from tumor cells was performed by using RNeasy Mini kit. The concentration and purity of the resultant RNA was assessed, complementary DNA was prepared by using Quant script reverse transcriptase and then amplified through $2 \mathrm{X}$ Maxima SYBR Green/ROX qPCR Master Mix (Thermo Scientific, \# K0221) and genespecific primers. The reaction volume and qPCR thermal conditions were performed. The melt curve was produced at the last cycle $\left(60-95{ }^{\circ} \mathrm{C}\right)$. The fold of change in the apoptotic related genes was determined by using the $2^{-\Delta \Delta \mathrm{Ct}}$ method and critical threshold quantities [21].

\section{Statistical analysis}

The individual data obtained from each experiment as mean \pm S.D. By using oneway ANOVA, the statistical differences between the experimental groups were addressed. The statistical significances were obtained at the $p$ values that of less than 0.05 .

\section{RESULTS:}

\section{Phytochemical contents of sweet red pepper extract}

Phytochemical constituents including total phenolic, total flavonoids, total antioxidant capacity (TAC) and scavenging activities of the DPPH radicals were determined in the extract aqueous ethanolic of sweet red pepper. The results showed that this extract exhibited potential phytochemicals content. The level of total phenolic compounds represented $1.292 \mathrm{mg}$ gallic acid equivalents (GAE) per $\mathrm{ml}$ of extract. Total flavonoids in the aqueous ethanolic extract of sweet red pepper were $0.159 \mathrm{mg}$ quercetin equivalent $/ \mathrm{ml}$ extract. The TAC using phosphomolybedate method was $0.138 \mathrm{mg} / \mathrm{ml}$. The percentage of inhibition by radical binding activity of $\mathrm{DPPH}$, and the inhibitory concentration that represented $50 \%\left(\mathrm{IC}_{50}\right)$ values were 
shown in figure. 1. Sweet red pepper extract was determined to be active in free radicals scavenging properties, the data of the present study denoted that the percentage of DPPH free radical scavenging activity caused by sweet red pepper extracts represented $64 \%$ and their $\mathrm{IC}_{50}$ value was $0.094 \mathrm{mg} / \mathrm{ml}$ (Figure 1).

Cytotoxic effect of sweet red pepper extract against colorectal cancer cell lines

Human colon tumor cell lines were treated with different concentrations of sweet red pepper extracts. Their cytotoxic and anti-proliferative effects were determined based on the ability of colorectal cancer cell lines to reduce MTT producing the formazan dye. As shown in figure $\mathbf{2}$, the results revealed that red pepper vegetables extracts exhibited selective cytotoxicity in the colon cancer cell lines with a potential cytotoxic effect to a minimum concentration killing $50 \%$ of colon cancer cell (IC50) $25 \mu \mathrm{g} / \mathrm{ml}$.

\section{Apoptotic effect of sweet red pepper extract against colorectal cancer cell lines}

Real time PCR was used to detect the relative expression of apoptosis related genes, Bax and caspace-3, and antiapoptosis gene, Bcl-2, that corresponding to the alterations in the transcription levels of these genes in cancer cells posttreatment with the extract under the study for 24 hours. To conduct real time PCR, we first isolated total RNA from $\mathrm{CaCo}-2$ cells. The isolated RNA was reversed transcribed into cDNA for qPCR. The housekeeping gene encoding GAPDH was used as an internal reference for normalization. The expression level of the target gene in control $\mathrm{CaCo}-2$ cells was considered the baseline. The results of qPCR demonstrated significant upregulation $(p \leq 0.05)$ in the expression level of the apoptotic gene, $\mathrm{Bax}$, in $\mathrm{CaCo}-$ 2 cells following treatment of the sweet red pepper extracts. A significant upregulation was reported 3.72 fold of change (Figure 3). Moreover, the expression level of the apoptotic gene, caspase-3, was up-regulated after treatment with the sweet red pepper extract for 24 hours with folds of change 6.28, when compared with control CaCo-2 cells without treatments (Figure 4). Downregulation in the expression level of the anti-apoptotic gene, $\mathrm{Bcl}-2$, in $\mathrm{CaCo}-2$ cells due to plants extract exposure with expression level (0.065) as compared to control group which showed fold of change 1 (Figure 5).

\section{DISCUSSION:}

Colorectal cancer is a complex disease caused by multiple cells signaling disruptions, its treatment is depends on using radiotherapy, chemotherapy, and surgery ${ }^{[22]}$. Chemotherapeutics could kill cancer cells through different mechanisms, for instance, DNA damage triggering, cell cycle arresting, and DNA repair inhibition. However, the cytotoxicity's of these chemotherapeutics, and resistance as well as the severe adverse reactions are major concerns ${ }^{[23]}$.

Due to the capability of natural products derived from plants to promote apoptosis and cell cycle arrest without toxic effect on the healthy cells, these natural compounds can be used for effective cancer prevention and treatment [24]. These natural constituents including alkaloids, polysaccharides, polyphenols and diterpenoid have become new promising anticancer agents. Currently, natural products enter in half of the used anticancer drugs in the markets ${ }^{[25]}$.

Interestingly, various species of Capsicum plants have been reported for their potential activities as antiinflammatory, anti-allergic and antimutagenic ${ }^{[13-16]}$. It has been reported that there was a strong relationship between the prevention the risk of certain types of cancer and vegetables intake with [26]. Therefore, in the present study, the phytochemicals constituents in the sweet red pepper extract were evaluated. The antioxidant activities of flavonoids which 
are beneficial to human health by scavenging harmful radicals have been addressed in the extract under the present study based on quercetin equivalent. The DPPH radicals are well known in the model system to evaluate the scavenging properties of numerous natural products. The scavenging activity of the prepared extract against DPPH radicals showed promising percentage. Our data were in accordance with the previous studies reported the phytochemical constituents in Capsicum plants [27].

The present study was extended for in vitro evaluation of the anti-proliferative effect of sweet red pepper extract against the colon cancer cells and the obtained results revealed that the inhibitory concentration that kills $50 \%$ (IC50) of cells for broccoli was low $(25 \mu \mathrm{g} / \mathrm{ml})$ indicating that this extract has a powerful anticancer efficacy. Our results were in line with previous study revealed the cytotoxic and genotoxic activities of Capsicum spp extracts ${ }^{[28]}$. Amruthraj et al. also reported the in vitro studies on the efficacy of some capsaicinoids as anticancer [29]. ChapaOliver and Mejía-Teniente also reported that Capsaicin plants showed cancersuppressing activity ${ }^{[30]}$. The potential anticancer activity of sweet pepper extracts was evaluated against breast (MCF-7) and prostate (PC-3) carcinoma cell lines in vitro ${ }^{[31]}$

It has been reported that most types of cancers express the anti-apoptotic proteins such as Bcl-2. Some of digestive organs including colon vigorously resist apoptosis [32]. The molecular mechanisms and the downstream regulatory signaling networks by which natural products do their anticancer effects have been reported ${ }^{[33]}$. Zhang et al. reported that Capsaicin enhances the antitumor activity via increased ERK signaling in hepatic cancer cells and experimental mouse tumors model ${ }^{[34]}$. In this study, the contribution of apoptosis induction in inhibiting colorectal cancer development after the treatment with sweet red pepper vegetables extracts was evaluated. Gene expression analysis results by using RT-PCR of apoptotic and anti-apoptotic related genes of colon cancer cell lines treated with the extract indicated that sweet red pepper extract enhanced apoptosis in colon cancer by upregulating apoptotic genes and downregulating the anti-apoptotic genes that might be related to the antioxidant properties of these extract. These could help in development of good therapeutic strategy in colon cancer treatment targeting apoptosis induction using naturally occurring vegetables without harmful effects on normal cells. The data in this study is agreed with the previous studies demonstrated the anticancer effect of Capsaicin plants against human cancers by inducing apoptosis ${ }^{[31,35]}$. Furthermore, it has been reported that Capsaicin vegetables could promote apoptosis in human lung cancer through binding the membrane calcium channel protein receptors known as TRPV6 and the downstream Calpain signaling pathway ${ }^{[42-}$ 36].

\section{CONCLUSION:}

Herbal medicine, in particular, Capsicum peppers have promising natural pharmacological bioactive constituents. The hydro-alcoholic extract of sweet red pepper showed antioxidant, anticancer efficacy, and inhibited the proliferation of colon cancer cells through inducing apoptosis. Therefore, Capsicum peppers plants are promising candidates for human health due to their powerful antioxidant and anticancer activities. Sweet red peppers are good source of compounds that could be beneficial for colon cancer treatment.

\section{REFERENCES:}

1. Ferlay J, Soerjomtaram I, Dikshit R, et al. Cancer inciidence and mortality worldwide: source, method in Globocan. Intern Journ Cancer 2015. 136:359-386. 
2. Siegell RL, Miler KD, Jemall A. Cancer Statistics. Cancer Journ Clinic. 2017. 67:7-30.

3. Terzić J, Grilvennikv S, Karim E, et al. Inflammation and colon cancer. Gastroenterol. 2010. 138(6):2102114.

4. Watson AM, Colins PD. Colon cancer disorders. Digestiv Disease. 2011. 29:222-228.

5. Floresc M, Cilnteza M, Vinereanu D. Cardiotoxicity induced by chemotherapy. Maedic. 2013. 8:5967.

6. Huange A, Many M, Jiny $B$. Chemotherapy-induced leukopenia prognosis in metastatic lung cancer patients treated with platinum chemotherapy. Intern Journ Clinic Exper Med. 2016. 9:5241-48.

7. Iqball J, Abbasii A, Mahmod T, et al. Anticancer agent derived from plant: Green anticancer approach. Asian Pacif Journ Tropic Biomed. 2017. 7:1129-150.

8. Khalajy L, Nejade C, Mohammadi M, et al. Evaluating competence of broccoli on antioxidant and inflammatory pathways in restraintinduced model: Estimation in hippocampus and prefrontal cortex of rat. Biomed Resear Intern. 2013. 2013:1-13.

9. Huange Y, Caiey Z, Zhange Y. Phenolic natural compounds from medicinal herbs and dietary plants: potential use for cancer therapy. Nut Canc. 2010. 62:1-20.

10. Lambert D, Hongy J, Yange Y, et al. Carcinogenesis inhibition by polyphenols: evidence from laboratory investigations. Americ Journ Clinic Nutr. 2005. 81: 284-91.

11. Eshbauge $H$. The Taxonomy of Capsicum genus. In: Peppers: Botany, Production and Uses, Russo, V.M. (Ed.). CABI International, UK. 2012. 13:14-28.

12. Oui B, Huangy D, Hampschwodwil $\mathrm{M}$, et al. Analysis of antioxidant activity of common vegetables employing oxygen radical absorbance capacity, a comparative study. Journ Agric Food Chemist. 2002. 50:312228.

13. Hervert-Hernandez D, Sayago-Ayerdi G, Goni I. Bioactive compounds of four hot pepper varieties (Capsicum annuum L.), antioxidant capacity and intestinal bioacessibility. Journ Agric Food Chemist. 2010. 58:3399-406.

14. Chen L, Kangy H. Anti-inflammatory and antioxidant activities of red pepper (Capsicum annuum) stalk extracts: Comparison of pericarp and placenta extracts. Journ Funct Foods 2013. 5:1724-31.

15. Puglies A, O'Callaghan $\mathrm{Y}$, Tundis R, et al. In vitro investigations of the bioacesibility of carotenoids from raw, frozen and boiled red chili peppers (Capsicum annuum). Eur Journ Nutrit. 2014. 53:501-10.

16. Carvalho V, Andrade R, de Oliveira Riose A, et al. Bioactive compounds and antioxidant activity of pepper (Capsicum sp.) genotypes. Journ Food Scien Technol. 2015. 52:7457-64.

17. Ekwer R, Udohe E. Extraction and comparative analysis of moisture and capsaicin contents of capsicum peppers. Journ Pain Relief .2016. 5:268.

18. Biro A, Gale F, Hegdus C, et al. Isolation of alithiamin from Hungarian red sweet pepper seed (Capsicum annuum). Heliyon. 2018. 4:e00997.

19. Ruemnel M, Schwartz S, Seidman G, et al. Colon cancer cell apoptosis is mediated via the mitochondrial pathway. Gut. 2003. 52:94-100.

20. Ebrahimzadeh V, Niknam $H$. Spectrophotometric method for assessing of triterpenoid saponins. Ind Drugs 1998. 35:379-381.

21. Livaek KJ, Schmitgen TD. Analysis of Relative Gene Expression Data Using Real-time Quantitative PCR 
and the $2^{-\Delta \Delta \mathrm{Ct}}$ Method. Methods. 2001. 25:402-8.

22. Schmoll J, Van E, Steins A. Guidelines for management of patients with colorectal cancer. Annal Oncol. 2012. 23:2479-516.

23. Woods D, Turcehie J. Chemotherapy DNA damage induced response: pathways and convergence of drugs. Canc Biol Therap. 2013. 14:379-89.

24. Shahehe F, Baradrann B, Majdii J. Echinophora platyloba crude extract induces apoptosis in human prostate adenocarcinoma cells (PC-3). Biomed Journ. 2014. 37:298-304.

25. Newman J, Cragg M. Natural products as sources of new drugs. Journ Natur Prod. 2016. 79:629-661.

26. Wolffe K, Wu X, Liu H. Antioxidant capacity of apple peels. Agricul Food Chemist. 2003. 51:609 -614.

27. Shaima A, Mahmod S, Mohammed R, et al. Phytochemical screening, antioxidant activities and in vitro anticancer potential of Egyptian Capsicum Spp. Biochemist Pharmacolo. 2016. 5:2.

28. Bertaoe MR, Moraese C, Palmierie A, et al. Cytotoxicity, genotoxicity and antioxidant efficacy of extracts from Capsicum spp. Resear. Journ Med Plant. 2016. 10:265-275.

29. Amruthrajy J, Raje P, Saravanan S, et al. In vitro studies on anticancer activity of capsaicinoid from Chinense Capsicum against human hepatocellular carcinoma cells. Intern
Journ Pharm Pharm Scien. 2014. 6:254-258.

30. Chapa-Oliver AM, Meja-Teniant L. Capsaicin: from plants to a cancersuppressing agent. Molec. 2016. 21:931.

31. Marshmman E, Oteewel D, Poten S. Caspase activation during spontaneous and radiation-induced apoptosis in the murine intestine. Patholo. 2001. 193:1-9.

32. Huang $X$, Yang $Z$, Xie Q, et al. Natural products for colon cancer treatment: A mechanistic review. Biomed Pharmacoth. 2019. 117:109142.

33. Zhang $\mathrm{S}$, Ni $\mathrm{H}$, Zhao $\mathrm{R}$, et al. Capsaicin enhances the antitumor activity of sorafenib in hepatocellular carcinoma cells and mouse tumors through increased ERK signaling. Acta Pharmacol. 2018. 39:438-48.

34. Lin $\mathrm{C}, \mathrm{Lu} \mathrm{W}$, Wange $\mathrm{C}$, et al. Capsaicin induces apoptosis and cell cycle arrest in human KB cancer cells. BMC Complem Alt Med. 2013. 13:46.

35. Clark R, Lee S. Anticancer properties of capsaicin against human cancer. Anticanc Resear. 2016. 36:837-44.

36. Friedman R, Perry E, Brown C, et al. Capsaicin synergizes with camptothecin to induce increased apoptosis in human small cell lung cancers via the calpain pathway. Biochem Pharmacolo. 2017. 129:5466. 


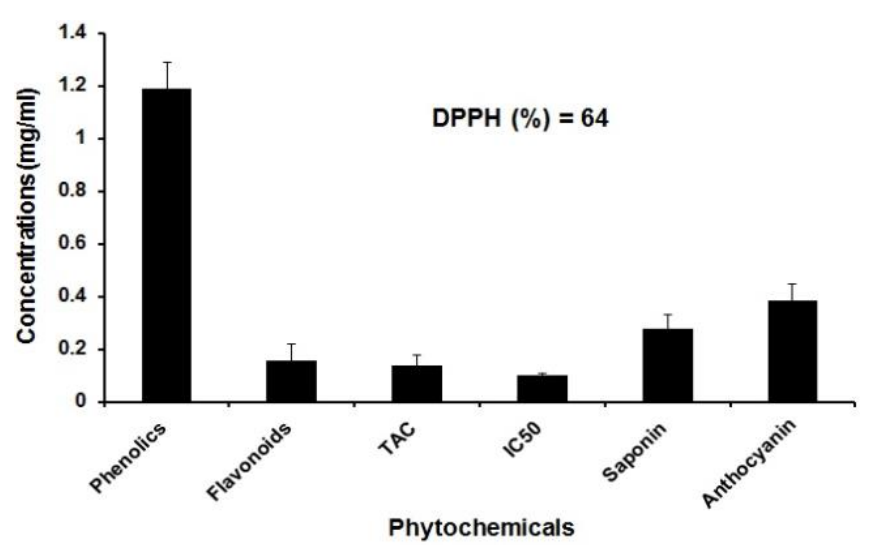

Figure (1): Phytochemicals analysis of sweet red paper extract (all units were $\mathrm{mg} / \mathrm{ml}$ ). TAC: Total antioxidant capacity, $\mathrm{IC}_{50}$ : Inhibitory concentration that that give $50 \% \mathrm{DPPH}$ scavenging activity.

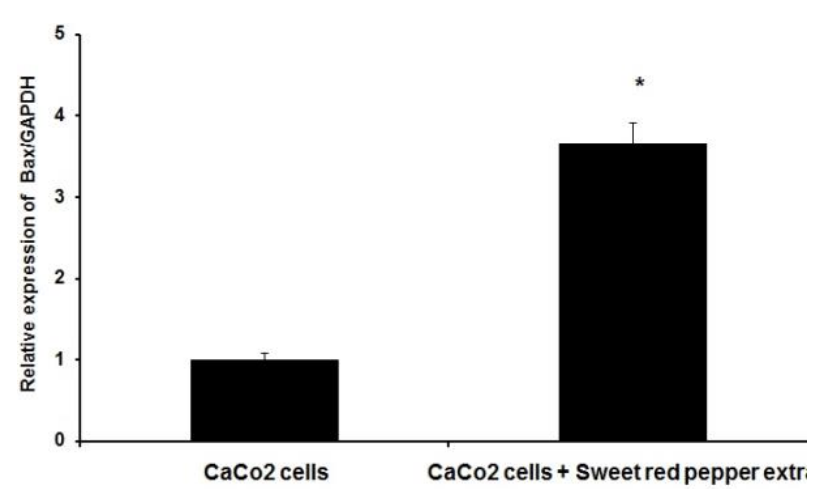

Figure (3): Real-time quantitative PCR analysis showing the expression of apoptotic related Bax genes in CaCo-2 cells after $24 \mathrm{~h}$ of sweet red pepper extract treatment.

* means significant change $(\mathrm{p} \geq 0.05)$.

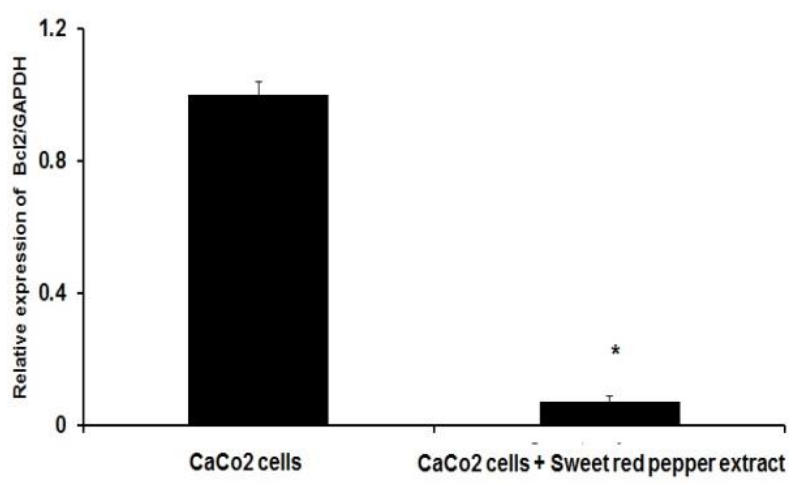

Figure (5): Real-time quantitative PCR analysis showing the expression of apoptotic related Bcl2 genes in CaCo- 2 cells after $24 \mathrm{~h}$ of sweet red pepper extract treatment.

* means significant change $(\mathrm{p} \geq 0.05)$.

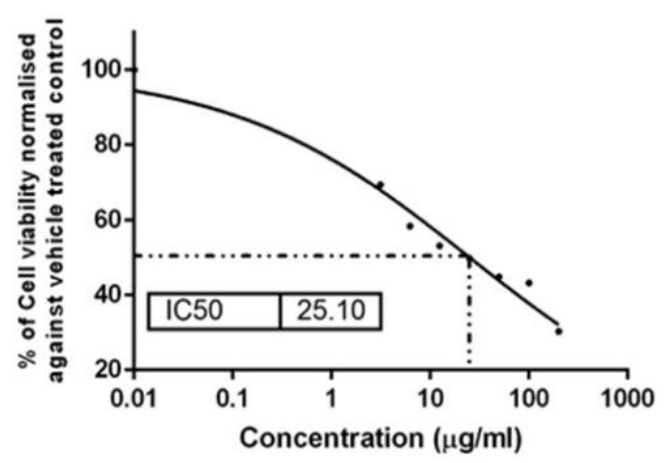

Figure (2): The viability of colorectal cancer cell lines post $24 \mathrm{~h}$ of sweet red pepper extract treatment.

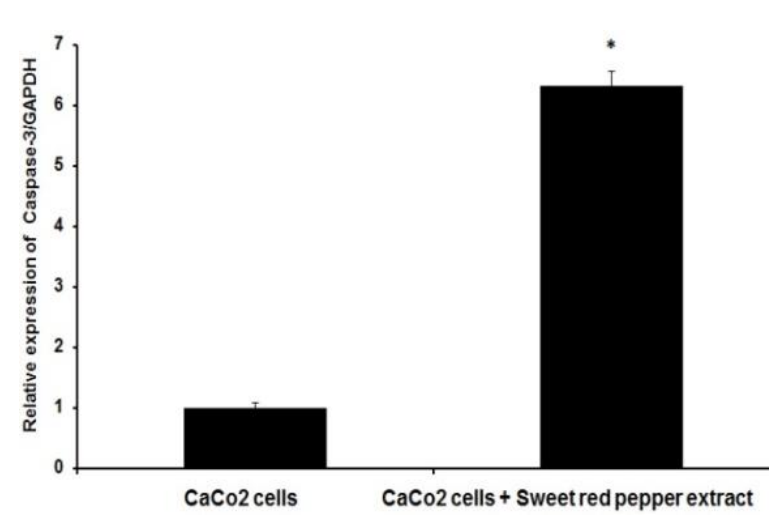

Figure (4): Real-time quantitative PCR analysis showing the expression of apoptotic related Caspase-3 genes in $\mathrm{CaCo}-2$ cells after $24 \mathrm{~h}$ of sweet red pepper extract treatment.

*means significant change $(p \geq 0.05)$. 